\title{
LEGISLATION'S INFLUENCE ON JUDICIARIZATION: EXAMINING THE EFFECTS OF STATUTORY STRUCTURE AND LANGUAGE ON RATES OF COURT USE IN CHILD WELFARE CONTEXTS
}

\author{
Angela Campbell $^{*}$, Mairi Springate ${ }^{* *} \&$ Nico Trocmé $e^{* * *}$
}

This paper investigates the extent to which legislation influences decisions of child welfare workers regarding the referral of cases to court. It studies three Canadian jurisdictions: Quebec, Ontario, and Alberta, each of which takes a different legislative approach to the issue of court involvement in child protection. A critical examination of child welfare statutes in these provinces led to the prediction that rates of court use - or 'judiciarization' - would be highest in Quebec, followed by Ontario, and then Alberta. These predictions were then compared with data reflecting actual judiciarization rates in these three provinces for the year 2006. This data contradicted our initial predictions, in that Ontario's rate of court use for child welfare cases was the highest of the three provinces, followed by Alberta, and then Quebec. Our research results thus suggest that legislation alone does not drive judiciarization in the child welfare context. As such, this paper illuminates the need for further study of the way in which child protection workers understand legislation as influencing their professional responsibilities and choices. Moreover, it indicates that further consideration is needed into how the use of judicial versus extra-judicial institutions might affect child welfare outcomes.

Cet article examine la mesure dans laquelle la législation influence les décisions des travailleurs et travailleuses du bien-être de l'enfance quant à soumettre des cas aux tribunaux. On étudie trois territoires canadiens: le Québec, l'Ontario et l'Alberta, dont chacun prend une approche législative différente à la question de la participation des tribunaux dans la protection de l'enfance. Un examen critique des lois sur la protection de l'enfance dans ces provinces a amené à prédire que le taux d'utilisation des tribunaux - ou la "judiciarisation" - serait le plus élevé au Québec, suivi de l'Ontario puis de l'Alberta. Puis on a comparé ces prédictions aux données indiquant le taux réel de judiciarisation dans ces trois provinces pour l'année 2006. Ces données ont contredit nos prédictions initiales, le taux d'utilisation des tribunaux pour les cas de protection de l'enfance ayant été le plus élevé

\footnotetext{
Faculty of Law, Centre for Human Rights and Legal Pluralism, and Centre for Research on Children and Families, McGill University. This research project was written with support from Valorisation Recherche Québec. The authors gratefully acknowledge the vital contribution of Elizabeth Fast in collecting and interpreting data discussed in this work. We also benefited from the able research assistance of Balkees Jarrah and Matthew Kanter.

** Faculty of Law and Centre for Research on Children and Families, McGill University.

*** Philip Fisher Chair in Social Work, School of Social Work, and Director, Centre for Research on Children and Families, McGill University.
} 
des trois provinces en Ontario, suivi de l'Alberta puis du Québec. Les résultats de notre recherche suggèrent donc que la législation à elle seule ne pousse pas à la judiciarisation dans le contexte de la protection de l'enfance. Ainsi, cet article fait voir le besoin d'étude additionnelle sur comment les travailleurs et travailleuses de la protection de l'enfance voient la façon dont la législation influence leurs responsabilités et leurs choix professionnels. De plus, il indique qu'il faut examiner davantage comment l'utilisation d'institutions judiciaires versus les institutions extrajudiciaires peuvent influencer les résultats de cas de bien-être de l'enfance.

\section{INTRODUCTION}

All provincial and territorial child welfare legislation throughout Canada envisions the possibility of court involvement in a number of different circumstances. Yet whether, when and for what purpose courts must or may be used in the administration of child welfare services varies from one statute to the next. This legislation also varies with respect to the extent to which child welfare matters can be managed through extra-judicial mechanisms. This paper aims to address whether and how the language and structure of child welfare legislation in Canada actually affects the frequency and nature of court involvement - or 'judiciarization' - in child welfare matters. It is a question that remains unexplored in current literature. That is, existing research tells us very little about how legislation shapes the choices and conduct of child welfare workers, especially insofar as the referral of cases to court is concerned. This paper seeks to address this gap in the scholarship through an investigation into the way statutory language and frameworks might influence judiciarization rates. We focus here on three particular provinces: Quebec, Ontario, and Alberta. These provinces vary broadly in terms of their respective legislative approaches to court involvement in child protection, and we thus expected that their statutory differences would result in divergent judiciarization rates.

This paper begins with a review of the literature relevant to the subject under consideration here. This discussion reveals the limited work that has been done to date on factors affecting child welfare workers' decisions and conduct. Part III undertakes an analysis of the child welfare statues in force in Quebec, Ontario, and Alberta with a view to identifying wording and regimes in each that might prompt or deter the referral of cases to court. From this analysis we draw predictions about relative judiciarization rates for each province. Part IV discusses our methodology and explains the challenges encountered in deriving data for rates of court use for child welfare matters. Finally, in Part V, we discuss our data findings. These findings in fact run counter to the predictions we formulated from our legislative analysis in Part III about judiciarization rates in the three provinces we study. Our discussion here examines potential factors that might have affected our findings, and comments briefly on the significance of court involvement in child welfare cases.

Ultimately, this paper uncovers more questions than answers. It is an initial attempt to examine whether legislation affects rates of court use. A project with 
a wider ambit, that tracked this question over a longer period of time, would perhaps result in more concrete answers. Yet, this paper nonetheless offers preliminary insights into the relationship between legislation and judiciarization in child welfare contexts. In so doing, it contributes to filling a substantial gap in doctrinal discussions about how courts are perceived and used for youth protection and welfare issues. This paper thus undertakes a rigorous analysis of different statutory approaches to child welfare, and seeks to assess the influence of legislative cues over actual outcomes for children and families deemed to be at risk. Moreover, this paper exposes a multiplicity of factors that might shape judicial involvement in youth protection. Finally, this work serves as a launching pad for the pursuit of further research oriented toward garnering a more robust appreciation of how courts can and should be implicated in the management and resolution of child welfare cases.

\section{LITERATURE REVIEW}

Our review of the social science and legal scholarship revealed that the particular issue we address in this paper, namely, the influence exerted by child welfare legislation over the rate of court use in child protection cases, has yet to be studied. Indeed, the interface between child welfare matters and use of judicial institutions has received very little attention by scholars. ${ }^{1}$ Despite this, we did locate articles addressing themes closely linked to our own focus. In particular, we found literature considering how various factors, including applicable child protection legislation, influence child welfare practices. While we did find a small number of studies identifying factors prompting judiciarization, this work did not consider how legislation might affect court use.

\section{A. Factors Influencing Child Welfare Decisions and Practices}

Existing scholarship has identified an array of factors that shape decisions and conduct adopted by child protection workers. While legislation is frequently identified as bearing influence over child welfare practices and decisions, as discussed below, the literature identifies a series of additional factors that prompt child protection choices, interventions, and outcomes.

\section{Legislation}

The impact wielded by child protection legislation over child welfare workers' interactions, professional decisions and conduct has been broadly studied. Howe's analysis of Canada's federalist structure's effects on the administration of child welfare matters posits that different levels of intervention seen in child welfare practices across the country can be partly attributed to the wording of, and policies underlying, provincial child welfare legislation. ${ }^{2}$ For example, the breadth of definitions found in statutes for terms like "child in need of protec-

1 Andrea J. Sedlak et al., "Child Maltreatment and the Justice System: Predictors of Court Involvement" (2005) 15 Research on Social Work Practice 389 at 390.

2 Brian R. Howe, "Implementing Children's Rights in a Federal State: The Case of Canada's Child Protection System” (2001) 9 Int'l J. Child. Rts. 361. 
tion," "physical abuse," or "emotional abuse" might affect the level of discretion held by child welfare workers vis-à-vis intervention. Child welfare interventions might also be influenced by a statute's mandatory reporting requirements, which vary across provinces. Moreover, where a statute identifies its primary purpose as the "best interests of the child" rather than "family preservation", greater levels of intervention might result. Howe's analysis thus provides a host of examples illuminating how legislative framing and terminology might have "on the ground" repercussions for child protection issues.

Khoo et al.'s research also suggests the potential influence of legislation over child welfare practices. ${ }^{3}$ In their comparative study of child welfare practices in Ontario and Sweden, the authors anticipated that differences in statutory vocabulary would affect practical decision-making. This was confirmed pursuant to interviews with child welfare workers in both jurisdictions. The researchers found that child welfare workers' decisions in Ontario are largely governed by legislative guidelines and parameters, which in turn drive standardized risk assessment protocols that agencies must follow. This stood in contrast to procedures in place in Sweden, which were more decentralized and marked by greater professional autonomy.

The compelling influence of legislation over the conduct and decisions of child welfare workers is further emphasized in studies examining the implementation of mandatory reporting requirements. This research emphasizes how a legislated duty to report affects social work practice, as well as child welfare outcomes. ${ }^{4}$

Other research has been more equivocal about the law's role in shaping child welfare practices. According to one study, legal requirements do little to improve substantive outcomes, noting: "legal controls are ineffective at raising standards and even at ensuring fairness." Levine's study also indicates that written legal "formulae" are unlikely to affect investigators' decisions regarding the actual treatment of child protection cases. ${ }^{6}$ In a related vein, other research indicates that child protection workers retain discretion and agency even in the face of relatively strict standardized protocols. ${ }^{7}$ Finally, a study by Kopels et al. examines factors underlying imperfect compliance with legislative requirements for child welfare practice, and suggests why this might in fact be acceptable. ${ }^{8}$

Moreover, some literature has shown that even when legislation modifies child

3 Evelyn G. Khoo, Ulf Hyvönen \& Lennart Nygren, "Gatekeeping in Child Welfare: A Comparative Study of Intake Decision-making by Social Workers in Canada and Sweden" (2003) 82:3 Child Welfare 507.

4 Van N. Dokkum, "The Statutory Obligation to Report Child Abuse and Neglect" (1996) Acta Juridica 163; Frank Ainsworth, "Mandatory Reporting of Child Abuse and Neglect: Does it Really Make a Difference?" (2002) Child and Family Social Work 57.

5 Judith Masson, “The Role of Law in Social Work with Children" (1989) Cambrian Law Review 38 at 51.

6 Murray Levine, "Do Standards of Proof Affect Decision Making in Child Protection Investigations?” (1998) 22 Law and Human Behaviour 341.

7 Henry Parada, Lisa Barnoof \& Brienne Coleman, "Negotiating Professional Agency: Social Work and Decision-Making within the Ontario Child Welfare System" (2007) 34 Journal of Sociology and Social Welfare 35.

8 Sandra Kopels, Taliah Charlton \& Susan J. Wells, "Investigation Laws and Practices in Child Protective Services” (2003) 82 Child Welfare 661. 
welfare practices, this will not necessarily translate into improved outcomes for children and families. It is argued that an increased emphasis on formal legal frameworks and institutions may result in child welfare workers aiming primarily to satisfy inflexible legal requirements rather than proactively seeking childcentered solutions tailored to the specific case at hand. For Anglin, more beneficial child outcomes are thus possible through a move away from "reductionistic legal constructs" in the provision of child welfare services. ${ }^{9}$

\section{Other Factors}

A number of studies consider other factors, aside from the applicable legislative structure, shaping decisions and practices adopted in the field of child protection. These factors are encompassed by five themes: resource availability; perceptions of risk; parental involvement and roles; the perceived relevance of corroboration; and personal traits of the worker, caregivers and children.

\section{(a) Resource availability}

The scope of public resources allocated to child welfare schemes in a given jurisdiction has been observed to influence professional practice. When governments curtail budgets for child welfare programs, agencies must focus on, and will only intervene in, crisis situations, whereas other families in need, though perhaps not in crisis situations, might not receive full services and support. ${ }^{10}$ As noted below, resource allocation and availability also influence judiciarization - or the propensity to turn to a court - in the child welfare context. ${ }^{11}$

\section{(b) Perceptions of risk}

An additional dynamic identified as a determinant of child welfare workers' decision-making was a worker's analysis of the "problem." McConnell et al. indicate that the worker's perception of where the challenge is situated (i.e., with a parent, the family, or within a broader community or social context) will determine the nature and type of intervention exercised. ${ }^{12}$ Workers' perceptions concerning the severity of risk posed to a child also affects their decisions. This has been studied in the context of child welfare workers' assessments and referral of borderline cases, ${ }^{13}$ as well as decisions regarding the pursuit of criminal charges in sexual and physical abuse cases. ${ }^{14}$

9 James P. Anglin, "Risk, Well-Being, and Paramountcy in Child Protection: The Need for Transformation" (2002) Child \& Youth Care Forum, 233 at 254

10 Howe, supra note 2; David McConnell, Gwynnyth Llewellyn \& Luisa Ferronato, "Contextcontingent Decision-Making in Child Protection Practice" (2006) 15 International Journal of Social Welfare 230; Lisa M. Jones, David Finkelhor \& Stephanie Halter, "Child Maltreatment Trends in the 1990s: Why does Neglect Differ from Sexual and Physical Abuse?” (2006) Child Maltreatment 107.

11 McConnell, Llewellyn \& Ferronato, ibid.

12 Ibid.

13 Dendy Platt, "Threshold Decisions: How Social Workers Prioritize Referrals of Child Concern" (2006) 15 Child Abuse Review 4.

14 Nico Trocmé \& Marc Tourigny, "Facteurs Associés à la Décision d'entreprendre des poursuites criminelles à la suite d'un signalement pour Abus Sexuel ou Physique Envers un Enfant" (2000) Criminol. 8 [Trocmé \& Tourigny, "Facteurs Associés à la Décision"]. 


\section{(c) Parental involvement and roles}

The role assumed by parents in a child protection context can also affect how child welfare workers perceive and deal with a case. In particular, parental cooperation can shape workers' assessment of risk; where it exists, intervention is less likely. ${ }^{15}$ In contrast, where parents are found accountable for the risk to which a child is exposed, this will result in a greater likelihood of an assessment and/or investigation. ${ }^{16}$

\section{(d) Perceived relevance of corroboration}

The desire to ensure 'success' if a case proceeds through formal (especially judicial) channels, and to avoid public criticism, can also influence child welfare workers' decisions and actions. As Poirier notes, "nothing horrifies bureaucracy more than publicity; many internal rules are drafted especially to avoid any public outcry." ${ }^{17}$ The importance of collecting proper documentation and other evidence to corroborate findings of maltreatment has thus been emphasized. ${ }^{18}$ Corroboration has also been stressed as essential to child welfare workers' decision-making regarding whether and how to respond to a child welfare referral. ${ }^{19}$ And Trocmés recent work found that a police referral and the presence of physical or emotional harm (especially multiple forms of harm) increase the likelihood that maltreatment would be classified as suspected rather than unsubstantiated. ${ }^{20}$ This finding also speaks to the relevance of corroboration in social work decision-making.

\section{(e) Personal traits}

While the foregoing research identifies correlations between contextual factors and child welfare practices, other research has considered the way in which personal traits - in particular, those of the worker, the child, and the caregiver - might influence child welfare interventions. Lazar's research in the Israeli context found that the degree of a child welfare worker's intervention was associated with the child's gender, the worker's gender, and the worker's level of "authoritarianism." ${ }^{21}$ Workers were found to respond more severely where cases involved girls, where the worker charged with managing the case was male, and where this worker displayed heightened levels of authoritarianism. Trocmé's study also indicates that the caregiver's ethno-racial status, as well as any risk factors to which the caregiver is subject (e.g., health concerns, domestic violence, alcohol or drug addiction) can influence decisions regarding substantiation. ${ }^{22}$

15 Nico Trocmé, "Differentiating between Substantiated, Suspected, and Unsubstantiated Maltreatment in Canada" (2008) [unpublished, on file with authors] [Trocmé, "Maltreatment in Canada"]; McConnell, Llewellyn \& Ferronato, supra note10.

16 Platt, supra note 13.

17 Donald Poirier, "Social Worker Enforcement of Child Welfare Legislation: an Increasing Potential for Abuse of Power" (1986) 5 Can. J. Fam. L. 215 at 233.

18 McConnell, Llewellyn \& Ferronato, supra note 10.

19 Platt, supra note 13.

20 Trocmé, "Maltreatment in Canada", supra note 15.

21 Ammon Lazar, "Determinants of Child Protection Officer's Decisions in Emergency Situations: An Experimental Study" (2006) Child Youth Care Forum 263 at 269

22 Trocmé, "Maltreatment in Canada", supra note 15. 


\section{B. Factors Influencing the Referral of Child Protection Cases to Courts}

Although we did not uncover any study examining the specific relationship between legislation and rates of judiciarization for child protection matters, we did locate three studies that identified other predictors of court use in the child protection context. ${ }^{23}$ These studies identify a range of factors that might work in conjunction with legislative cues to prompt the referral of cases to court. McConnell et al., identified five such factors: the likelihood that outcomes will improve as a result of court involvement; the severity of the case relative to others managed simultaneously; the strength of the evidence; the extent to which child welfare workers felt they were making satisfactory progress without court involvement; and resource constraints. ${ }^{24}$

A second study based upon data from California enumerated four key predictors for court referral: the extent to which families cooperate with (or at least remain neutral vis-à-vis) the child protection agency; the extent to which allegations of maltreatment are substantiated; confirmed drug use within the family; and the scope of support available to the family. ${ }^{25} \mathrm{~A}$ couple of overlaps with McConnell et al.'s conclusions regarding court use are noteworthy. First is the finding that where a family has support - be it offered through the state or private channels - court referral is less likely. Second, an emphasis on substantiation as a predictor of judiciarization emerges in both studies. This reflects "a strong legal-evidentiary approach to cases" pursuant to which court referral is unlikely if the evidence regarding maltreatment is not compelling. ${ }^{26}$

Sedlak et al.'s study reports on predictors for referral of cases to "dependency" courts (i.e., courts responsible for ordering the provision of services to a child/ family/caretaker, or the removal or placement of a child) and to criminal courts. ${ }^{27}$ Their focus was on cases involving neglect or abuse so flagrant that criminal prosecutions were contemplated or pursued. The identified predictors for court referral pertained primarily to the personal characteristics of the perpetrator of the abuse/neglect and those of the child. This emphasis distinguished their work from that of McConnell, Llewellyn \& Ferronato and Karski; both of these works looked to situational and contextual factors likely to prompt court referral. Sedlak et al. identified numerous personal traits as predictors of dependency court use: the perpetrator's age; the difference in age between perpetrator and victim; the perpetrator's sex; the perpetrator's racial/ethnic background; the presence of other, ongoing problems for the perpetrator (e.g., drug/alcohol abuse); the victim's age; the victim's sex; the victim's race and ethnicity; and prior victim impairment/disability. They also noted other factors, not related to victim or perpetrator identity, which seemed to predict court use: the type of abuse; the number of victims involved; the number of perpetrators involved; the relationship between perpetrator and victim and their living arrangement; and the case's point of entry into the system.

23 McConnell, Llewellyn \& Ferronato, supra note 10; Sedlak et al, supra note 1; Ruth L. Karski, "Key Decisions in Child Protective Services: Report Investigation and Court Referral" (1999) 21 Children and Youth Services Review 643.

24 McConnell, Llewellyn \& Ferronato, supra note 10 at 234.

25 Karski, supra note 23 at 650

26 Ibid. at 654 .

27 Sedlak et al, supra note 1. 
Although this existing research on factors prompting court use is instructive for our purposes, no study addresses the Canadian child welfare landscape, nor does the research consider how statutory requirements might operate to prompt or discourage court proceedings. We thus seek to add to this scholarship by examining the specific ways in which legislative language and cues might influence rates of court use. In the discussion that follows we offer an analysis of three child welfare statutes, from which we draw expectations as to rates of judiciarization in each province. These expectations are later compared to actual rates of court use for child protection matters in these provinces within a particular timeframe.

\section{LEGISLATIVE ANALYSIS}

For the purpose of identifying possible correlations between a province's child welfare legislation and its rate of court use for child welfare matters, we examined three statutes, focusing on indicators that might either prompt or deter reliance on courts. These statutes were Quebec's Youth Protection Act (YPA), ${ }^{28}$ Ontario's Child and Family Services Act (CFSA), ${ }^{29}$ and Alberta's Child, Youth and Family Enhancement Act (CYFEA). ${ }^{30}$ Through our analysis we identified four particular factors within each statute as the best predictors for the rate of court use for child protection issues in each province:

- the presence of provisions that allow directors of child welfare services to rely on alternative dispute resolution (ADR) for child protection issues;

- the extent to which directors may enter into negotiated agreements with youth, their families, and communities to develop child protection strategies;

- situations in which directors have no discretion but to use courts to pursue certain interventions; and

- the provision of community services designed to prevent the need for more intrusive interventions that require judicial authorization.

Our data regarding rates of court use derive from cases deciding on appropriate

28 R.S.Q. c. P-34.1 [Youth Protection Act]. It should be noted that while working on the research for this paper, Quebec's YPA was amended by Bill 125, An Act to Amend the Youth Protection Act and other legislative provisions, $1^{\text {st }}$ Sess., $37^{\text {th }}$ Leg., Quebec, 2005 (assented to 15 June 2006), S.Q. 2006, c.34 [Bill 125]. This Bill is relevant to the objectives of this paper, in that it sought to encourage the active participation of children and parents in child welfare decision-making, and to reduce reliance on courts and tribunals. See Bill 125, Explanatory Notes. However, given that this legislative reform occurred in 2007, after the time period that was our concern, our discussion of legislation in Quebec focuses primarily on the YPA as it stood prior to these amendments. Nevertheless, at various points in this discussion we signal amendments that might have had an influence on the data collected.

29 R.S.O. 1990, c. C-11 [Family Services Act].

30 R.S.A. 2000, c. C-12 [Child Youth Act]. 
measures for dealing with children and families who fell under the radar of public youth protection services in each province. Our legislative analysis, then, does not explore statutory provisions that direct judicial involvement in procedural or administrative matters (e.g., acquisition of search or apprehension warrants, allowing public access to hearings, or allowing public identification of a child or family involved in a youth protection proceeding). Our analysis also excludes consideration of the adoption provisions within child welfare statutes.

The discussion that follows sets out the statutory treatment of the four predictors enumerated in Quebec, Ontario, and Alberta. It seeks to assess how legislation in each province might channel the players in provincial child welfare systems through the courts, or conversely, how it might divert them from court use. The final part of this section sets out expectations created by each province's legislation as to the rate of court use for child welfare matters.

\section{A. Contemplation of Alternative Dispute Resolution (ADR)}

A key benefit of ADR methods (e.g., mediation, arbitration, family conferencing) lies in their ability to divert cases from overburdened judicial institutions bound to follow formal procedures that might limit parties' ability to voice freely their claims and concerns. ADR allows more direct involvement in the discussion, negotiation, and decision-making processes by the parties to a case than is ordinarily permitted in formal litigation. Thus, because parties may appropriate a degree of ownership over - and responsibility for - outcomes, ADR is commonly associated with parties benefiting from more satisfaction with results and decisions than adjudication might yield. At the same time, and as discussed below, some literature is more tentative in its assessment of ADR's promise, especially where parties are vulnerable or lack equal bargaining stature. ${ }^{31}$

Of the three statutes we considered, both Ontario's CFSA and Alberta's CFYEA contemplate the use of ADR for resolving contentious issues related to child protection. Quebec's YPA does not integrate mediation or any other form of $\mathrm{ADR}$ as an explicit option for reaching outcomes in child protection matters, although as discussed below, the statute does facilitate the negotiation of outcomes with children and families in some circumstances. ${ }^{32}$

In 2006, a provision was added to the Ontario CFSA directing any agency designated as a Children's Aid Society (CAS) in the province to consider whether ADR would promote the resolution of issues arising where a child is in need of protection. ${ }^{33} \mathrm{~A}$ CAS is required to consider ADR as a possible option in these circumstances, but is not bound to follow this course. ${ }^{34}$ If the child concerned is Aboriginal, the CAS must consult with her "band or native community" to determine whether an ADR process established by the band or community, or some other prescribed process, would assist in resolving the issues raised. ${ }^{35}$ The

31 See Part IV, below, for a discussion of the potential benefits and drawbacks of ADR in the child welfare context.

32 See discussion in Part B, below.

33 See Bill 210, The Child and Family Services Statute Law Amendment Act, $2^{\text {nd }}$ Sess., $38^{\text {th }}$ Leg., Ontario, 2006 (assented to 28 March 2006) S.O. 2006, c.5.

34 Family Services Act, supra note 29, s. 20.2(1).

35 Ibid., s. 20.2(2). 
Aboriginal child's band or community also has a right to receive notice of any proposal to proceed through ADR in a child welfare matter. ${ }^{36}$

In addition to this, an Ontario court might refer any matter associated with a child welfare proceeding before it to ADR after an adjournment. This is only possible, however, where such adjournment is consistent with the child's best interests and if the parties to the proceeding consent. ${ }^{37}$

The Alberta CYFEA entered into force in November 2004 as legislation oriented toward the prevention and provision of support and services to "at risk" families, with a view to averting situations of crisis. To this end, the statute explicitly envisions the possibility of parties' reliance on ADR to reach outcomes related to child welfare. Section 3.1 allows the child, her guardian, or a person with "a significant connection" to her, or the Director of Children's Services to reach an agreement to enter into ADR proceedings regarding any decision affecting the child. ${ }^{38}$ Thus, unlike the Ontario model, which generally directs - except where a case involves an Aboriginal child - the CAS to determine unilaterally whether $\mathrm{ADR}$ is appropriate, the Alberta legislation anticipates direct involvement from the child and her family in making this decision.

\section{B. Opportunities for Child Welfare Workers to Negotiate Outcomes Dir- ectly with Youth, Families, and Communities}

All three statutes envisage possibilities for youth, families, and sometimes even community members, to negotiate intervention strategies with workers and agencies. Permitting such involvement in reaching outcomes for children and youth can allow the relevant actors to exercise agency in the process of ensuring the security and development of children considered at risk. This presents an opportunity to express interests and to have their voices represented in the outcomes achieved. We posit that the greater the breadth of such opportunities, the greater the satisfaction there will be with solutions developed for children and youth, and the less likely parties will be toturn to courts to settle matters.

In Quebec, the involvement of families and youth in negotiating methods for ensuring a child's security and development is witnessed through the "voluntary measures" regime. The YPA stipulates that where the Director of Youth Protection finds that a child's security or development is endangered, he may either propose the application of "voluntary measures" or refer the matter to a court. ${ }^{39}$ Yet, such voluntary measures can only be implemented if the child's parents and the child herself, if aged 14 or older, agree to the application..$^{40}$ Where these parties do consent to pursue voluntary measures, they are bound to make a written agreement with the Director incorporating measures that seek to "put an end to

\footnotetext{
Ibid., s. 20.2(4).

37 Ibid., s. 51.1.

38 See specifically Child Youth Act, supra note 30, s.3.1(1). Furthermore, ss. 3.1(2)-(4) also integrate measures to ensure that the confidentiality of the proceedings is protected.

39 Youth Proteciont Act, supra note 28, s. 51.

40 Ibid., s. 52, para. 1. Note that generally, agreements for the application of voluntary measures are made between the Director and both of a child's parents. However, the Youth Protection Act recognizes that there may be circumstances in which such an agreement should be formed with just one of the parents. See ss. 52.1, 32, para. 2.
} 
and prevent the recurrence of the situation in which the security or development of the child is in danger." ${ }^{11}$ The Director may propose, and the parties may agree to, a spectrum of voluntary measures that vary in terms of level of severity and intrusiveness into family life. ${ }^{42}$

Although the YPA casts the Director, the child, and her family as bearing primary responsibility for designing and applying voluntary measures, the obligation also seems to extend beyond these players to the broader community. For example, the Director must, where possible, "call upon persons or bodies active in the community where the child lives" for the purpose of implementing voluntary measures. ${ }^{43}$ Furthermore, the statute charges "every institution and every educational body" with the duty of contributing, to the extent of their means, to the implementation of these measures. ${ }^{44}$

This expansive accountability for applying voluntary measures in Quebec does not preclude judicial involvement even where such measures initially are pursued. If parties fail to settle on the particular voluntary measures that will be applied within 10 days and the child's security or development remains in danger, the Director must refer the matter to a court. ${ }^{45}$ Moreover, if a child aged 14 or over, or a parent who is a party to the agreement, withdraws from this agreement and the child's security or development remains in danger, the Director is again required to proceed to court. ${ }^{46}$ And given that agreements for voluntary measures have fixed terms, if upon their expiry a child's security or development is still considered to be in danger, the situation must at that point be referred to a court. ${ }^{47}$ Thus, while voluntary measures could serve to divert child welfare matters in Quebec from formal judicial processes, the YPA nonetheless envisions courts as the final arbiter where agreements cannot be reached, break down, or fail to protect a child's security and development. ${ }^{48}$

41 Ibid., s. 52, para. 2.

42 Pursuant to $i b i d$., s. 54, the Director may propose different types of voluntary measures: "(a) that the child remain with her family and that parents report periodically to him on measures they apply in their own regard or in their child's regard to put an end to the situation in which the child's security or development is in danger; (b) that the child and the child's parents undertake to take an active part in the application of the measures; $(c)$ that the parents ensure that the child not come into contact with certain persons or that certain persons not come into contact with the child; $(d)$ that the child undertake not to come into contact with certain persons; $(e)$ that the parents entrust the child to other persons; $(f)$ that a person working for an institution or body provide aid, counseling, or assistance to the child and her family; (g) that the parents entrust the child to an institution operating a hospital centre or a local community service centre or to another body so that she may receive necessary care and assistance; (h) that the child or her parents report in person, at regular intervals, to the director to inform him of the current situation; (i) that the parents ensure that the child receive required health services; $(j)$ that the parents entrust the child for a fixed period to an institution operating a rehabilitation centre or to a foster family, chosen by the institution operating a child and youth protection centre; $(k)$ that the parents ensure that the child attend a place of learning other than a school and that the child undertake to do so; $(l)$ that the parents undertake to ensure that the child attend a childcare establishment.

43 Ibid., s. 54, para. 2.

44 Ibid., s. 55.

45 See ibid., s. 52, para. 3.

46 Ibid., s. 53.1, para. 1.

47 Ibid., 53.1, para. 3.

48 The Youth Protection Act also stipulates that a child and her parents are entitled to be informed 
The Ontario CFSA also clearly imagines possibilities for involving youth and families in negotiating outcomes. Aside from its explicit integration of ADR as a mechanism for resolving matters related to child welfare, ${ }^{49}$ the statute includes other provisions that direct participation by youth, families, and even communities in designing strategies to assist children in need of protection. This is also evident in the CFSA's statement of purpose, which requires children's services to be provided in a manner that "includes the participation of a child, his or her parents and relatives and the members of the child's extended family and community, where appropriate." ${ }^{50}$ The statute goes on to define members of a child's community, identifying them as persons with "ethnic, cultural or religious ties in common with the child or with a parent, sibling or relative of the child" or those with "a beneficial and meaningful relationship with the child or a parent, sibling or relative of the child." 51

In keeping with its goal of providing child welfare assistance "on the basis of mutual consent" where possible, ${ }^{52}$ the CFSA contemplates situations in which children and families must be consulted about, or must consent to, the provision of services. Thus, a child aged twelve or more must consent to the provision of counseling services, ${ }^{53}$ and all other child protection services can be provided to a person aged sixteen or older only with that person's consent or with a court order. ${ }^{54}$ In addition, the provision or cessation of residential services - whereby the young person is removed from her regular home or the home of her parents generally requires parental consent where the child is younger than sixteen years of age. ${ }^{55}$ Although the child's consent in these cases is not required, her wishes, if ascertainable, must be taken into account. ${ }^{56}$

In other contexts, a child or family's involvement in determining child welfare

by the Director of all circumstances that require him to refer a matter initially channeled through voluntary measures to a tribunal. See s. 53.1, para. 2 .

Note should be made here of recent amendments to the Youth Protection Act that, while not affecting rates of court use during the timeframe under consideration here, remain interesting given their likely future influence on judiciarization in child welfare matters. These amendments explicitly encourage child and family involvement in negotiating outcomes with youth protection workers. See e.g., Bill 125, supra note 28, s.2 (amending ibid., s. 2.3), which provides that child welfare interventions must favour means that allow children and their parents to "take an active part in making decisions and choosing measures that concern them;" and Bill 125, supra note 28, s.3 (amending ibid., s. 4), which directs the involvement of the child, parents, and community in all decisions affecting youth protection. Insofar as voluntary measures are concerned, see Bill 125, supra note 28, s.20 (amending ibid., s. 51), which states that before such measures are proposed or before the matter is referred to a tribunal, the director must "recommend a consensual approach, where the situation allows it, to encourage the active participation of the child and the child's parents."

49 Family Services Act, supra note 29, s. 20.2.

50 Ibid., s. 1(2)3(iv).

51 Ibid., s. 3(3).

52 Ibid., s. 1(2)1.

53 Ibid., s. 28.

54 Ibid., s. 27(1).

55 Ibid. s. 27(2), (4). The same is also true of a transfer of a child's residential placement: see s. 27(5).

56 Ibid., s. 27(6) 
outcomes is facilitated by provisions allowing them to reach agreements with a CAS. For example, a person with custody of a child may agree to place her in the temporary care of a CAS. ${ }^{57}$ Similarly, a person having custody of a child with special needs might obtain services for that child or agree to entrust responsibility for her supervision or her care and custody to a CAS or the Minister of Community and Social Services. ${ }^{58}$

Lastly, the CFSA lists as one of its goals the provision of services in a way that recognizes "that Indian and native people should be entitled to provide, wherever possible, their own child and family services, and that all services to Indian and native children and families should be provided in a manner that recognizes their culture, heritage and traditions and the concept of the extended family." ${ }^{59}$ [Emphasis added] Thus, while the statute's provisions permitting family involvement in negotiating outcomes apply in cases involving Aboriginal children, the significance of such participation, and the idea of communities directing processes and outcomes, is underscored in these contexts.

Like Ontario's CFSA, Alberta CYFEA's contemplation of family involvement in negotiating child welfare solutions is illuminated through its explicit integration of ADR. ${ }^{60}$ Aside from this, the statute envisages possibilities for the Director of Child Welfare to enter into various types of agreements with families to ensure a child's security and well-being. "Family enhancement agreements," for example, are designed to provide services in a way that allows children in need of protection to remain in their usual homes. These agreements may be reached between the Director and a child's guardian or custodian where the Director finds a child in need of intervention and where the services provided pursuant to the agreement would adequately protect the child's "survival, security or development." ${ }^{\prime 1}$ The Director may also make custody agreements and permanent guardianship agreements with a child's guardian. Custody agreements result in the child's placement with someone other than her usual guardian for a set period of time (not more than six months), whereas a "permanent guardianship agreement" involves the Director's assumption of sole guardianship of the child for all purposes. ${ }^{6}$ Finally, where a court renders a "temporary guardianship order," ${ }^{63}$ the Director is authorized to make agreements permitting access to the

57 Ibid., s. 29.

$58 \mathrm{Ibid}$., s. 30. It is also possible for the young person with a special need aged 16 or 17 to make such an agreement for her own care and the services provided to her. See ibid., s. 31 .

59 Ibid., s. 1(2)5.

60 Child Youth Act, supra note 30, s. 3.

61 Ibid., s. 8 ..

62 See ibid., ss. 9,10, which set out the terms of a custody agreement, and s. 11 which sets out the requirements of a permanent guardianship agreement. Note that if reaching an agreement is impossible, the Director may seek temporary or permanent guardianship of a child through a court application: see ibid., ss. $17 \& 18$.

63 Temporary guardianship orders are issued by a court where intervention is needed and the child's survival, security or development cannot be adequately protected if she remains with her usual guardian, even though it is anticipated that she can be returned to the custody of her guardian within a reasonable time, or that - if she is over 16 years of age - she will be able to live independently. See ibid., s. 17. 
child by her guardian or any person having a significant relationship with her. ${ }^{64}$

While the foregoing arrangements in the CYFEA envisage the conclusion of agreements between the Director and the child's guardian(s), the statute also foresees possibilities for youth to become directly involved in negotiations with child welfare workers. That is, where a young person aged 16 or older is considered to be in need of intervention, she may agree with the Director to receive child welfare services or to be placed in the Director's exclusive custody. The legislation requires such agreements to include a plan preparing the youth for "the transition to independence and adulthood." "65

Finally, similar to the Ontario CFSA model, the CYFEA suggests that communities might also have a role to play in negotiating child welfare outcomes, particularly where Aboriginal child welfare issues arise. The statute sets out circumstances in which the Director of Child Welfare is bound to consult and work with a designated member of a child's band council in planning for the services that a child receives. ${ }^{66}$ It is anticipated that such involvement will facilitate the child's retention of her culture, identity, language, history, and connection to her community. ${ }^{67}$

\section{Situations in Which Directors must use Courts to Pursue Certain Ac- tions}

A third factor that we interpreted as potentially influencing rates of court use was the extent to which a statute compelled judicial authorization for certain interventions. We predicted that legislation requiring such authorization more frequently would contribute to a higher overall rate of judiciarization. We note, however, that the statutory provisions we discuss here are only those where a Director's discretion in pursuing an intervention is limited and he must proceed before a court. We do not consider the many provisions in each statute that permit, but do not require, applications to be made to a court.

In Quebec the YPA's urgent measures regime ${ }^{68}$ requires judicial involvement regardless of whether parents and children agree to its application. These measures might involve the Director's immediate removal of a child from his present environment and entrusting this child to an institution, a foster family or any other "appropriate body." ${ }^{69}$ While the child and her parents must generally be consulted, ${ }^{70}$ they need not consent to the application of urgent measures. Rather, where a child or parent objects, the Director is entitled to compel consent, but must submit the matter to a tribunal "with the least possible delay."

64 Ibid., s. 14.

65 Ibid., s.57.2.

66 Ibid., s.107.

67 Alberta Child and Youth Services, "Overview of Changes to the Child, Youth, and Family Enhancement Act" (August 2004) online: Government of Alberta, Child and Youth Services $<$ www.child.gov.ab.ca/whatwedo/enhancementact/pdf/CS\%20Overview $\% 202 \% 20$ low.pdf $>$

68 Pursuant to the July 2007 amendments to the Youth Protection Act, supra note 28, these measures are now termed "immediate protective measures."

69 Ibid., s. 46.

70 Ibid., s. 47, para. 1.

71 Ibid., s. 47, para. 2. The necessity of judicial intervention where urgent measures are applied 
Furthermore, the Director can never apply urgent measures for more than 24 hours without a judicial order. ${ }^{72}$ Finally, it is also important to recall that while the YPA integrates a "voluntary measures" regime allowing the Director to reach agreements with families extra-judicially, this framework also envisions compulsory court use in some circumstances. ${ }^{73}$

The Ontario CFSA includes provisions that compel judicial intervention in certain contexts. In particular, where prior consensual arrangements expire but a CAS still deems a child to require protection, the matter must be referred to a court. ${ }^{74}$ Moreover, if a child protection worker has apprehended a child without judicial authorization, the matter must proceed before a court for a child protection hearing "as soon as practicable" and within five days after the child is brought to a place of safety. ${ }^{75}$ If a child has been brought to a place of safety that is a place of open temporary detention, the matter must be brought to the court within 24 hours. $^{76}$

Furthermore, where a court deems a child to be in need of protection and orders either that she be placed under CAS supervision or named a ward of a $\mathrm{CAS},{ }^{77}$ the CAS in question must appear before the court to review the child's status before the original order for supervision or wardship expires. ${ }^{78}$ In the event that a court conducts a status review and finds that the child's best interests are served by placing her in the care and custody of a particular person (and possibly again subject to CAS supervision), ${ }^{79}$ the CAS is bound to seek status review before a court once more under the same terms. ${ }^{80}$

Like its counterparts in Quebec and Ontario, the Alberta CYFEA mandates court use where the Director seeks to invoke the most intrusive child welfare measures. The apprehension of a child thus requires a court application if the child is not returned to the custody of the guardian within two days of her removal. ${ }^{81}$ Moreover, if the Director seeks a temporary or permanent guardian-

against the will of a family is underscored by ibid., s. 74, which provides, "The director shall refer the matter to the tribunal where the parents or the child are opposed to the application of an urgent measure."

72 Ibid. s. 47, para. 2.

73 See supra notes 18-21 and accompanying text.

74 This occurs at the end of special needs agreements (see Family Services Act, supra note 29 s. 33(3)(b)), and where temporary care agreements expire or are set to expire (see s. 33(5)(b)).

75 Ibid., s. 46(1)(a).

76 Ibid., s. 46(2).

77 See ibid., s. 57.

78 Ibid., s. 64(2)(b), this is unless the order expired because the child reached the age of majority or married. See ibid., s. 71(1). Note, however, that if the CAS has removed a child from the care of the person named as the child's custodian pursuant to the original supervisory order, the CAS must appear before the court for status review within five days of such removal: see ibid., s. $64(2)(c)$.

79 See ibid., s. 65.2(1)(a) and (b).

80 That is, before expiry of the order, or within five days if the child was removed from the care of the person with whom she was placed pursuant to a supervisory or custody order. See ibid., ss. 65.1(2)(b) and (c).

81 Child Youth Act, supra note 30, s. 21(1). In disposing of such an application, the court may issue any one of four orders: supervision order, temporary or permanent guardianship order, an order returning the child to the guardian's custody, or an order placing the child with child welfare authorities in another province. 
ship order, he must seek a judicial order placing the child in his custody until the main application is withdrawn or decided. ${ }^{82}$ Finally, if the Director confines a child pursuant to a secure services certificate, ${ }^{83}$ he must appear before a court within three days to justify the need for this intervention. ${ }^{84}$

A court appearance is also necessary where the guardian of an apprehended child refuses essential medical, surgical, or dental treatment for that child; in these cases treatment can only follow a court order authorizing it. ${ }^{85}$ The same requirement exists where a child subject to a temporary or permanent guardianship order refuses essential treatment. ${ }^{86}$

\section{Provision of Community-based Services}

As a final indicator, we considered provisions that directed the use of community services for youth and families considered 'at risk.' We hypothesized that the inclusion of such provisions in legislation could serve to avert crisis situations that trigger the need for more interventionist measures typically ordered through court processes.

Quebec's YPA requires both the provision of information about communitybased resources to help families, as well as actual community services, in various contexts. Where a child's security or development is found to be in danger, the Director must provide her and her family with information about community services and conditions for accessing them. ${ }^{87}$ The same information must be provided where the Director decides to end an intervention involving a child ${ }^{88}$

Actual community-based services must also be offered pursuant to the YPA. The statute signals a child's general entitlement to "receive adequate health services, social services and educational services, on all scientific, human and social levels, continuously and according to his personal requirements." ${ }^{89}$ The provision of such resources could be viewed as a method for preempting blunt interventions that would trigger court involvement. In addition, community services must be provided where voluntary measures are applied and the Director calls upon community actors to facilitate their application. ${ }^{90}$ And where the Director

82 Ibid., s. 21.1(1).

83 A "secure services certificate" is issued as a last resort measure where the Director has reasonable and probable grounds to believe that the child presents an immediate danger to herself or others that can only be reduced by confining the child to "stabilize and assess" her. See ibid. s. 43.1(1).

84 Ibid., s. 43.1(3)(a).

85 Ibid., s. 22.1(2).

86 Ibid., s. 22.2(1). CfQuebec Youth Protection Act, supra note 28, s. 48, para. 2, which allows the Director to authorize necessary medical services and other care without consent or a judicial order where "urgent measures" (now "immediate protective measures," see supra note 68) are applied.

87 Youth Protection Act, ibid, s. 50, para. 2.

88 Ibid., s. 57.2, para. 1.

89 Ibid., s. 8. Note that the wording of this amendment is altered to some extent by Bill 125, supra note $28, s .5$, which extended the right to receive adequate health services to the child's parents, and changed the standard for extending services from those necessary "according to his personal requirements" to those that "are appropriate from a scientific, human and social standpoint."

90 Youth Protection Act, ibid., s. 54, para. 2. See also s. 55 and discussion at supra notes 16-17. Note that the voluntary measures might themselves require children and their families to access and 
reviews cases involving children taken into his or her charge or placed in foster care, a need to consider community services again might arise since this review might result in a proposal for measures to assist parents, which might involve community-based resources. ${ }^{91}$

Although Ontario's CFSA includes within the definition of "services" offered to children and families "community support services," plicit as to when community-based services should be offered in lieu of more formal arrangements. There are, however, some indications that child welfare workers should attempt to alleviate situations of risk for children through community-based measures where possible. For example, temporary care agreements (which result in the transfer of the child's care and custody to a CAS) can only be made where it is found that "no less disruptive action" - especially the provision of care in the child's own home - would be appropriate. ${ }^{93}$ Special needs agreements also foresee the provision of services to meet a child's needs where the person(s) ordinarily having custody are unable to do so, ${ }^{94}$ or where a child aged 16 or older and no longer in parental care requires this assistance. ${ }^{95}$

Finally, the CFSA integrates a "homemaker" or "personal support worker" regime designed to allow individuals in need of support to receive necessary services in their homes and communities. A child welfare agency in Ontario may thus decide that a child in need of care or supervision can remain in her ordinary residence with the placement of a homemaker on the premises. This person may be authorized to enter and live in the residence with the child, provide housekeeping activities associated with the child's care, and exercise "reasonable control and discipline" over the child. ${ }^{96}$ In this way, the model facilitates the provision of care and support to children and families while avoiding apprehension. It is also noteworthy that judicial involvement is not required for establishing homemaker services.

Alberta's focus on community outreach services is communicated by its "differential response" model which privileges family supports and intervention suited to the distinct needs of each child. ${ }^{97}$ While this model is not defined explicitly in the CYFEA, it is explained at length in the policy documents that accompanied the enactment of this statute in $2004 .^{98} \mathrm{~A}$ key element of the dif-

make use of community-based services and resources. See e.g., s. 54(f), which would require that the family receive aid, counseling, or assistance from "a person working for an institution or body;" s.54 (g), which would compel parents to entrust their child to health or community services centre or to "another body" for the provision of necessary care and support; and s.54(k), which requires the child to attend a place of learning other than a school.

91 Ibid., ss. 57.1, 57.2.

92 See Family Services Act, supra note 29, s. 3.

93 Ibid., s. 29(4)(b).

94 Ibid., s. 30.

95 Ibid., s. 31.

96 Ibid., s. 78.

97 Alberta Children and Youth Services, supra note 67 at 8.

98 Alberta Children and Youth Services, "Alberta Enhancement Act Policy Manual" [rev. March 2007]. See also Jane Waldfogel, The Future of Child Protection: How to Break the Cycle of Abuse and Neglect (Cambridge: Harvard University Press, 2001) 137ff for a description of the differential response model. 
ferential response model is the concept of the family enhancement agreement which, as described above, ${ }^{99}$ allows the Director of Child Services to reach agreements with families for the provision of support and services at home and in the community. ${ }^{100}$ The statute requires the Director to pursue such agreements where a child is found to be in need of intervention, provided that this would effectively meet the child's needs. ${ }^{101}$ This model reflects the CYFEA's explicit emphasis on avoiding, where possible, interventions that disrupt or dismantle the family unit, in particular through the removal of a child from the family home. ${ }^{102}$

\section{E. Overview}

In some respects the statutory frameworks we considered revealed similarities. This was especially evident when considering the legislative provisions that compelled court use in particular circumstances. Child welfare statutes in Quebec, Ontario, and Alberta all require court involvement where more intrusive interventions are pursued, such as apprehending a child and entrusting her care to a person or institution other than her usual custodian or guardian. While there is some variation as to other situations that might trigger mandatory judicial involvement (e.g., the forced provision of health services over a child or parent's objections; the review of a child's status; and upon the expiry or breakdown of a consensual arrangement), the differences here were not so stark that they would suggest any obvious difference in rates of court use.

Other parallels in the legislative schemes were also apparent. For example, all three statutes envision possibilities for the Director of Child Welfare Services or child welfare workers to try to reach consensual arrangements with children and families, possibly even with community involvement. All three statutes further refer to the provision of community services for ensuring child welfare as falling within the purview of child welfare workers and administrators.

Having said this, some important features of the legislative regimes render each distinct. These distinctive characteristics led us to expect that Alberta would have the lowest rate of court use for determining outcomes in child welfare cases, with Quebec having the highest rate, and Ontario falling somewhere between the two, but likely closer to the Albertan rate. We drew this inference on the basis of various factors. The most salient was the Alberta CYFEA's emergence from a "differential response model" that emphasizes home and community services and youth and family participation in devising child welfare strategies. This orientation signaled that more intrusive measures requiring court intervention (e.g., apprehension and secure services certificates) would only be used where home- and community-based services were deemed inappropriate. The legislation also underscores the significance of community consultation and participation where the children in question are of Aboriginal heritage.

Alberta's CYFEA further stands out for explicit reference to ADR as a method

99 See supra note 34.

100 Child Youth Act, supra note 30, s. 8.

101 Ibid., ss. 6(2) and (3).

102 Ibid., s. 2(e)(i). 
for reaching outcomes affecting children and their families, especially since it is to be pursued upon agreement among the relevant parties, rather than following a unilateral decision by the Director. Legislative commentary associated with this reform to the Alberta statute reveals how ADR methods in this area are perceived as lending themselves to the effective and efficient resolution of outcomes for youth and families, thus suggesting an objective of court avoidance through these mechanisms. ${ }^{103}$ The statute also integrates families and youth in reaching various types of child welfare agreements (family enhancement agreements, custody agreements, and permanent guardianship agreements). That these agreements can be reached extra-judicially suggests a reduced need to turn to courts in this jurisdiction.

While Ontario's CFSA bears many features similar to the Alberta CYFEA, some are less pronounced. We therefore anticipated that rates of court use for determining child welfare matters would be somewhat higher in this province. For example, even though Ontario directs the consideration of ADR in child protection cases, the relevant CFSA provisions are quite recent (having been added through amendment in 2006), and thus would have had a minimal impact on rates of court use for child welfare matters during the time period studied here. ${ }^{104}$ Nevertheless, the CFSA's statement of purpose emphasizes the participation and, where possible, the consent of children, families, and communities in reaching child welfare solutions.

This objective is manifest in CFSA provisions requiring family and youth consultation and consent for certain interventions, as well as provisions permitting agreements with a CAS about particular interventions. Such measures could prompt voluntary extra-judicial solutions over court use in a number of settings.

Similar to Alberta, an emphasis on home- and community-based services for child welfare also emerges in the CFSA, especially through the homemaker regime. But while the Alberta CYFEA is clear that these services should be considered before more intrusive measures are pursued, the Ontario CFSA does not signal when community resources should be offered as an alternative to formal proceedings. Finally, it is noteworthy that the CFSA underscores the role of communities in pursuing child welfare strategies in circumstances involving Aboriginal youth.

In contrast to the CYFEA and the CFSA, Quebec's YPA includes fewer explicit measures likely to reduce the judiciarization of child welfare matters. For example, there is no reference to ADR or any other formal method for reaching solutions with families and children extra-judicially. A possible exception to this

103 Alberta, Legislative assembly, Hansard, (10 March 2003) at 391 (Harvey Cenaiko). Online: Legislative Assembly of Alberta < http://www.assembly.ab.ca/Documents/isysquery/b5d458ffc5c4-4839-b2bf- 42614104c847/1/doc/>

104 The inclusion of ADR provisions in the Ontario Child and Family Services Act had similar policy motivations as those underlying the comparable initiative in Alberta. ADR was promoted as a means for looking "beyond the courtroom" to more efficient methods that would generally yield positive outcomes for youth and families, and a concomitant lightened reliance on formal interventions. Ontario, Legislative Assembly, Hansard, (1 November 2005) at 1620 (Hon. Mary Anne V. Chambers). 
is the voluntary measures regime, but Quebec's Director of Youth Protection is not bound to apply this regime, which appears to be an option that only coexists with the possibility of referring a case to court. Furthermore, even when voluntary measures are applied, a number of situations could result in the case still proceeding before a court.

Additionally, although community-based services, and information about them, must be provided to children and families in Quebec in certain circumstances, the YPA places less emphasis than the CYFEA and the CFSA on providing home- and community-based resources to children at risk. There is nothing in the YPA that compares to the family enhancement services delivered under the auspices of Alberta's differential response model. Nor is there anything akin to the homemaker model developed in Ontario's CFSA. Finally, unlike the Alberta and Ontario statutes, the YPA does not include explicit measures to integrate community participation or to avoid judiciarization in cases involving Aboriginal youth and families. For all these reasons, we expected Quebec to have the highest rates of court use for child welfare cases. ${ }^{105}$ This hypothesis is supported by earlier scholarship examining judicial interventions in matters affecting young people in Quebec, which found a drastic increase in the reliance on courts for youth protection and youth criminal justice matters, despite legislative "déjudicarization" initiatives. ${ }^{106}$

\section{METHODOLOGY}

More than two decades ago, Poirier noted in a study focusing on the move toward increased voluntary arrangements and reduced court use in child welfare contexts that, "It is not easy to gather statistics from every year comparing the number of cases diverted from the courts through voluntary agreements with the number that actually went through the court." 107 Our experience was no different. It remains extremely difficult to isolate or categorize child protection cases, with a view to identifying how many proceed before a court versus how many are managed extra-judicially.

105 Note, however, that Quebec has the lowest rate of child welfare investigations involving Aboriginal children. In other Canadian jurisdictions, an average of 15 percent of cases of substantiated maltreatment involve children of Aboriginal heritage (Canada, Public Health Agency, Canadian Incidence Study of Reported Child Abuse and Neglect- 2003 (Minister of Public Works and Government Services Canada, 2005) at 70. Interestingly, studies have found that in Quebec only five percent of children who are the object of child protection investigations are Aboriginal (see Trocmé et al, Étude sur l'incidence et les caractéristiques de la maltraitance signalée a la Direction de la protection de la jeunesse au Québec: La Situation en 2003, (September 2007) at 46 on file with author. However, Aboriginal children often receive different treatment from child protection services in Quebec, with 25 percent of cases involving Aboriginal youth resulting in the child being taken into custody compared to only 14 percent of cases involving non-Aboriginal children (Marc Tourigny et al., "Incidence of Maltreatment of Aboriginal Children Reported to Youth Protection in Quebec: Intercultural Comparisons" (2007) 3 First Peoples Child and Family Review 84 at 92

106 Jean Trépanier, "La justice des mineurs au Quebec: 25 ans de transformations (1960-1985) (1986) 19:1 Criminologie 189

107 Poirier, supra note 17 at 227. 
Our own research sought to identify figures representing rates of court use in each province, with a view to juxtaposing these rates against our predictions about court use that we drew from our legislative analysis. Initially, we set out to uncover rates of court referral in every Canadian province and territory. However, the way in which child protection data is collected, defined, and organized varies widely from one Canadian jurisdiction to the next, making a national study of this kind impossible with the resources at our disposal. We therefore narrowed our focus to examine legislation and court referral rates in three provinces: Quebec, Ontario, and Alberta. We selected these provinces because their respective child welfare statutes differed in important aspects that could potentially lead to diverse child welfare responses. Consequently, our view was that results generated from this initial research could illuminate the way in which legislation might affect judiciarization throughout all of Canada. Having said this, ours is a preliminary study and its results should not be generalized or extrapolated to other provinces before national data is collected and analyzed. This paper is thus seen as a point of departure for a broader pan-Canadian study.

As discussed in the preceding section, we began our research by analyzing features in the relevant Quebec, Ontario, and Alberta statutes that might prompt child welfare workers to rely either on courts or extra-judicial methods in managing their cases. This legislative analysis led us to anticipate that Quebec would be the leader in terms of judiciarization rates, followed by Ontario, and then by Alberta.

We proceeded to collect data on actual rates of court use in child welfare cases in these three provinces for the year 2006. We chose 2006 as a focal year because data from 2007 was not as readily available in every province. A drawback of using 2006 data as our focal year is that it might not reflect changes prompted by recent legislative amendments promoting extra-judicial mechanisms. Moreover, we recognize the inherent - although unavoidable - limits within our design, which concentrates on just one year of information. However, we ensured that, for each province, we gathered at least one additional year of court use rates, which served as a point of reference to test the accuracy of our findings for 2006. ${ }^{108}$ Data from other years was also helpful in ensuring we could track whether recent legislative changes were having an impact over time. A final point worth underscoring regarding our decision to focus on 2006 data is that information from prior years would not track shifts in rates of court use that might have been triggered by the legislative developments of interest to our study, given that reforms focusing on extra-judicial methods occurred only shortly before 2006. As such, our focus on one year of data (namely, 2006) was necessary, and permits our research to offer important insights into the effects that legislative initiatives may or may not exert over actual child welfare practices.

Relevant data was collected through detailed communication, extending over a two-year period, with provincial government workers responsible for gathering child welfare information. From these exchanges, we were able to discern how many children in each province saw their cases proceed before a child welfare court. In order to avoid counting a child 'in the system' more than once in our

108 Although not published here, court referral rates for Quebec, Ontario, and Alberta in other years are on file with the authors. 
data, we did not include status reviews (i.e., reviews by the court of a case in which a decision or order had already been made) in our numbers.

Our largest challenge in accumulating the relevant data was ensuring its comparability. Given the different ways in which information about court use for child welfare cases is collected and organized in each province, we devoted extensive consideration to developing a methodological approach that would yield figures for each jurisdiction that could be meaningfully compared. Thus, for each province, we sought to identify means that would allow us to count only those cases for which court proceedings had been initiated in a given year. That is, our focus was the point of entry into the court system for cases in each jurisdiction.

For Quebec, we relied on the "nombres d'orientations judiciarisées pour chaque problématique" as compiled in the provincial chart "Indicateurs Repères 1998-1999 a 2006-2007"109 This data served as the best indicator of the number of individual children brought before child welfare courts given that it reveals the number of cases for which court processes have been initiated in a given year. Relying on this number allowed us to avoid duplication in the data since each child whose case is judiciarized must pass through this "orientation" stage, which normally occurs just one time.

Court rates in Ontario were determined with reference to two automatic collection systems in place since 2006: FRANK and SUSTAIN. ${ }^{110}$ This data derives from both the Ontario Court of Justice and the Family Court branch of the Ontario Superior Court of Justice and represented the number of judiciarized cases opened in a particular year. Although Ontario has no process similar to Quebec's "orientation" stage, the data provided for Ontario was comparable, seeing as it indicated how many cases proceeded to court were opened (i.e., initiated) in a given year. Yet, unlike data in Quebec and Alberta, which indicates numbers of individual children involved in court proceedings, this information collected in Ontario reflects the number of child protection proceedings. Because more than one child might be involved in a given proceeding, it was necessary to reconfigure the data so as to identify how many individual children were involved in cases referred to court. This would render the Ontario data comparable to the two other provinces considered. The assessment of the Ontario data thus involved combining the number of proceedings from both Ontario courts and multiplying this sum by 1.25 , a figure representing the average number of children per family brought before the courts for each family proceeding. ${ }^{111}$ In addition, and as discussed below in Part $\mathrm{V}$, the Ontario data proved to be somewhat difficult to harmonize with that of Quebec and Alberta as it captured all cases proceeding to

109 Document provided by Carole Lessard, Services des Jeunes et des Familles, Ministère de la Santé et des Services Sociaux. [Unpublished, on file with authors].

110 Data released through Brandon Parlette, Counsel at the Court Services Division of the Civil Policy and Programs Branch, Ministry of the Attorney General.

1111.25 is the average number of child proceedings per family proceeding in Quebec and Alberta as determined by the Etude sur l'incidence et les caractéristiques de la maltraitance signalée a la Direction de la protection de la jeunesse au Québec 2003, supra note 105, as well as administrative information from Alberta Children Services. We used these sources for the 1.25 multiplier because similar administrative numbers on the average number of children per family going to court were not available from Ontario. 
court in a given year, regardless of the stage at which a case was judiciarized. In contrast, data in the two other provinces captured only those cases judiciarized at their initial point of orientation or classification.

Data from Alberta was released to us via Information and Management and Information Strategies, Alberta Children and Youth Services, ${ }^{112}$ which sent us records from the 2006 fiscal year indicating the number of individual children who had been the subject of a child protection order in that year. We assured that the Alberta data captured cases at their point of entry into the court system by focusing only on judiciarized cases that were opened in the year 2006 .

The number of individual children whose cases were brought before the courts in 2006 in each province was then compared to the relevant province's total child population in this year to determine rates-per-thousand. The relevant child population was determined by the way in which "child" is defined in each province. For example, in Ontario, children aged 0-15 can be the subject of child welfare interventions, whereas data from Quebec and Alberta included children aged $0-17$, based on the statutory definition in these provinces of a child as being anyone less than 18 years of age. ${ }^{113}$

\section{FINDINGS AND DISCUSSION}

Our findings (displayed in Table 1) contradicted expectations generated by our statutory analysis. The highest judiciarization rate for child welfare matters in 2006 was in Ontario (4.44 per 1000), whereas Quebec's rate was the lowest (3.34 per 1000), and Alberta's rate fell between the two (4.27 per 1000). These rates were similar to those that we collected for other years in each province.

While the disparities in results appear rather slight, a couple of factual and practical points must be underscored given that they suggest a larger variance in actual rates of judiciarization within the three provinces under study. First, Quebec's statutory definition of a child whose security or development may be "in danger" is broader than corresponding definitions in the Ontarian and Albertan legislation. ${ }^{114}$ By including children with "serious behavioural disturb-

112 "Child Intervention Orders Started in Alberta"Merrilyn Greig-Gaudette, Information Management and Information Strategies, Ministry Support Services, Alberta's Children Services. [Data unpublished, on file with authors].

113 Although the definition of a "child" in the Ontario Family Services Act, supra note 29, includes a person up to (but not including) age 18, Ontario's provision of child welfare services is limited to children aged 0-15, whereas the relevant age range in Quebec and Alberta is 0-17. See also Trocmé et al, "Canadian Incidence Study of Reported Child and Neglect (2003)" Minister of Public Works and Government Services.

114 Unlike Ontario and Alberta, children are "in need of protection" in Quebec not only when subject to circumstances of neglect or abuse, but also upon exhibiting "serious behavioural disturbances," a term defined at Youth Protection Act, supra note 28, s.38(f) as a "situation in which a child behaves in such a way as to repeatedly or seriously undermine the child's or others' physical or psychological integrity, and the child's parents fail to take the necessary steps to put an end to the situation or, if the child is 14 or over, the child objects to such steps." The definitions of children "in danger," "in need of protection," and "in need of intervention" are set out at ibid., ss. 38.1, Family Services Act, supra note at 29, 37(2), and Child Youth Act, supra note 30, ss.1(2), (2.1), (3) respectively. 
ances," Quebec casts a larger net in terms of the scope of children investigated and likely also in terms of the number of cases that move before the courts. Were Ontario and Alberta to include this category within their respective statutes, it is very possible that their judiciarization rates would be higher, resulting in an even greater breadth in data outcomes.

Second, because of the way that court data is collected and organized in Ontario, our judiciarization numbers for that province are probably higher than they should be, when compared with those of Quebec and Alberta. More specifically, Ontario tracks all child welfare cases that proceed to court during a calendar year, regardless of whether court proceedings occurred at the outset of a file or whether it occurred only after other, non-judicial steps were taken to offer child welfare services. However, in Quebec and Alberta, cases only appear as being judiciarized in the data if court involvement occurred at the initial or "orientation" stages of a file. Thus, if non-judicial means were used to deal with a case at its outset, but upon review and at a later point in the same year that case proceeds to court, the file would not appear in either the Quebec or Alberta data as being judiciarized. While there were no means for us to harmonize the data to render it more comparable, we emphasize that differences in provincial approaches to tracking child welfare cases could have wielded a considerable influence over the results yielded by our study. In particular these differences likely resulted in numbers for Ontario that are higher than they would have been had data been uniformly produced.

As our findings belay our expectations, we conferred with colleagues in the relevant provincial ministries, and we inquired with them about our data and methods of calculation. Though some concern was expressed about the potential for duplication in the data, ${ }^{115}$ our colleagues agreed that our findings provide a reliable measure of court use in their respective jurisdictions.

Table 1: Rates of Court Use for Child Welfare Cases (2006)

\begin{tabular}{lllll}
\hline & $\begin{array}{l}\text { Age range } \\
\text { covered by } \\
\text { child protection } \\
\text { statutes }\end{array}$ & $\begin{array}{l}\text { Child population } \\
\text { for age range }^{1}\end{array}$ & $\begin{array}{l}\text { Protection } \\
\text { proceedings } \\
\text { initiated in } \\
2006\end{array}$ & $\begin{array}{l}\text { Proceedings per } \\
1000 \text { children }\end{array}$ \\
\hline Alberta & $0-17$ & 775,175 & 3,313 & 4.27 \\
Ontario & $0-15$ & $2,382,050$ & 10,575 & 4.44 \\
Quebec & $0-17$ & $1,549,205$ & 5,176 & 3.34 \\
\hline
\end{tabular}

1 Statistics Canada "Age (123) and Sex (3) for the Population of Canada, Provinces, Territories, Census Metropolitan Areas and Census Agglomerations, 2001 and 2006 Censuses - 100\% Data Tabulation” online: Stats Canada, 2006 Census of Population <http://www. statcan.gc.ca>.

This data set bears several implications. The most obvious of these is that legisla-

115 In particular, our contact from the Ontario Ministry of Child and Youth Services noted that a child might be counted twice if an application to the court was commenced, discontinued, and a new application started. Also, a case transferred from one jurisdiction to another would be counted as 'new' to the second location and thus counted twice. However, these numbers would be very small and would not impact significantly on our findings. 
tion, by itself, will not alter, prompt, or dissuade particular child welfare decisions and practices, particularly those related to the referral of cases to court. Should policymakers deem that child welfare outcomes would improve either by increasing or decreasing the frequency of court referrals in this area, amending the applicable child welfare legislation will not suffice. Rather, achieving the desired result would require reform through multiple axes, targeting the range of factors that might shape child welfare practice.

Moreover, the data we derive through this project offer only aggregate numbers, and do not reveal any qualitative information about the families or children appearing before child welfare courts in Alberta, Quebec, and Ontario. More work is needed to learn about the identities of the youth and families who move through these courts, so as to determine whether judicial institutions are equipped to manage their cases effectively. For example, suppose that a large percentage of families appearing before child welfare courts are impoverished, or of ethno-linguistic minority background. If so, accessibility to legal representation and to adequate translation services will be essential. This paper thus calls for heightened attention to be given to the identities of children and families involved in child welfare proceedings, so as to mitigate the alienation and trepidation that they might experience in their encounters with judicial institutions and formal rules.

\section{A. Other Factors Potentially Influencing Our Findings}

Our data suggests that the structure and wording of child welfare legislation has little impact on child welfare practices, in particular, on decisions regarding whether to refer a case to court. However, a more profound consideration of the issue reveals two factors that might explain more fully the reasons underlying the contradiction between our initial expectations and the data we uncovered: first, our exclusion of status reviews within our calculations; and second, the role of informal rules (deriving, for example, from policies and guidelines) that influence child welfare decisions and practices.

\section{Exclusion of Status Reviews}

To avoid a repeated counting of the same case in determining the rates-perthousand of children whose cases were judiciarized, we excluded status reviews, that is, proceedings in which a court is called upon to review an initial decision or order in light of new facts. Had these reviews been included, our findings would have been much closer to our hypothesis regarding court use. More specifically, Quebec had the highest number of status reviews in both 2006 and 2007 (23, 483 and 22, 942 respectively), followed by Ontario $\left(8,041\right.$ and 8,106), ${ }^{116}$ with Alberta having the lowest number $\left(5,499\right.$ and 5,172). ${ }^{117}$

116 The data indicates that there were 4,964 status review proceedings in Ontario in 2006 and 5,004 in 2007. However, because Ontario data tracks proceedings, which can encompass more than one child, we multiplied these numbers by 1.62 to arrive at the number of children whose cases were reviewed. According to our calculations 1.62 is the average number of children brought before the court per family proceeding in Ontario in 2003.

117 Data released through Merrilyn Greig-Gaudette, Information Management and Information Strategies, Ministry Support Services, Alberta's Children Services. [Unpublished, on_file with authors]. 


\section{Informal Normative Forces}

As this study suggests, child welfare practice is motivated by more than just formal law. Factors such as lessons learned from past experiences and the customs, habits, and expectations of the work environment can bear considerable influence over workers' decisions. ${ }^{18}$ Moreover, even when legislative requirements mandate specific conduct, child welfare workers might still conserve discretion, ${ }^{119}$ the exercise of which might be subject to informal standards and the culture of the relevant agency.

As such, the rates of judiciarization that we derived might be best explained through a broader analysis of the wide array of normative forces shaping child welfare practice, particularly with respect to judiciarization. ${ }^{120}$ If the discourse and culture within an agency is such that reliance on the courts is a habitual or trusted course of conduct, this might explain higher rates of court involvement. Furthermore, the culture, habits, and expectations within the agency might bear an influence on the nature and scope of child welfare investigations. Factors prompting a lower threshold for investigation might in turn result in fewer cases coming under the scrutiny of state child welfare authorities, and thus, a diminished likelihood of proceeding before a court.

Having said this, we note that the correlation between informal professional standards and child welfare practices has yet to be comprehensively studied. ${ }^{121} \mathrm{We}$ suggest that this is a topic ripe for consideration. Although legislation may wield considerable influence over child welfare decisions made 'on the ground,' further exploration as to how this influence compares to that exerted by 'soft laws,' such as agency guidelines or policies, is needed. The latter might be used for training purposes, are often framed in more accessible language than a statute, and might be referred to more often within intra-agency communications. An empirical study examining child welfare workers' perceptions of the normative weight of policies and guidelines, particularly in contrast to that of formal law, would thus have important academic and practical relevance. In particular, it would illuminate where the core motivators of child welfare practice lie, and the instruments that would require modification in the event that policymakers and legislators sought to redirect child welfare practices with a view to improving outcomes.

Finally, it should be noted that a number of more specific factors may be encompassed by child welfare standards and guidelines, which might also influence professional decisions and conduct. Such factors are discussed in the literature reviewed above: the resources with which an agency must work; perceptions regarding the importance of evidence; the substantiation of claims of mistreatment and abuse; the emphasis placed upon parental and familial consultation and cooperation; and concerns regarding the public's opinion of, and trust in, the operative child welfare system. These factors might explain our data findings, although again, it is worth exploring further the way in which Canadian child

118 Johan Glad, "Co-operation in a Child Welfare Case: A Comparative Cross-National Vignette Study" (2006) 9 European Journal of Social Work 223.

119 Levine, supra note 6; Parada et al., supra note 7; Kopels et al., supra note 8; Poirier, supra note 17.

120 Trépanier, supra note 106.

121 Poirier, supra note 17 at 233. 
welfare workers perceive these as forces shaping their professional decisions and conduct, particularly vis-à-vis the referral of cases to court.

\section{B. The Role of Courts in Child Welfare Contexts}

Before concluding, it is important to include a brief qualitative statement on the role of courts in child protection matters. Our discussion so far has not communicated any normative statement in this regard, and this paper thus should not be interpreted as taking a particular stance on the benefits or drawbacks of using formal proceedings to manage or settle child protection issues. At the same time, it remains important to highlight this issue as one meriting further attention.

The potential promises and pitfalls of relying on courts to settle legal disputes has been explored in considerable depth. Discussions on this issue that occur within family and child welfare contexts frequently culminate in a recommendation promoting mediation or other forms of ADR, provided proper conditions for such measures exist. ${ }^{122}$ This position is taken given how difficult court proceedings can be for families and young people, as a result of various factors: the intimidation and sense of disengagement, submersion, and alienation that results from the formality and rigidity of the proceedings; the risk of "secondary victimization" for children asked to testify; ${ }^{123}$ the cost and time involved; ${ }^{124}$ and the power imbalance between families and child welfare workers, ${ }^{125}$ the latter often viewed as bearing unlimited resources and more familiarity with judicial processes. ${ }^{126}$ In this connection, the funneling of cases through adversarial court procedures has been observed to trigger breakdowns in communications with child welfare agencies, ${ }^{127}$ and an inability to address the complexities of cases due to the inflexibility of legal rules applied in judicial contexts. ${ }^{128}$ Moreover, courts are not always perceived as impartial arbiters, and have been cast as serving to "rubber-stamp social work decisions." 129

On the other hand, families and children might find some reassurance in seeing their cases proceed before a court. Judiciarization offers a setting in which procedural guarantees are followed and parents might view this as operating to set checks and balances on child welfare workers' discretion and power, which is

122 Marvin M Bernstein, "Child Protection Mediation: Its time has Arrived" (1998) 16 Can. Fam. L.Q. 76; Gerry McNeilly, "Mediation and Child Protection: An Ontario Perspective" (1997) 35:2 Fam. Ct. Rev. 206; Linda Crush, "The State of Child Protection Mediation in Canada" (2005) 24 Can. Fam. L.Q. 219; Linda Crush, "Child Protection Mediation in Ontario: Which Way Forward?” (2007) 51:1 Ontario Association of Children's Aid Societies Journal 11; Sally E. Palmer, "Mediation in Child Protection Cases: An Alternative to the Adversary System" (1989) 68 Child Welfare 21; Nancy A. Flatters, "A Family/Child Judicial Dispute Resolution (JDR): An Overview of one Canadian Court-Settlement Conference Approach to the Pre-Trial Resolution of Family and Child Welfare Protection Matters" (2003) 41 Fam. Ct. Rev. 182.

123 Sedlak et al., supra note 1 .

124 Gary C. Dumbrill, "Parental Experience of Child Protection Intervention: A Qualitative Study" (2006) 30 Child Abuse \& Neglect 27.

125 June Maresca, "Mediating Child Protection Cases" (1995) 74 Child Welfare 731.

126 Dumbrill, supra note 125.

127 Maresca, supra note 126; Palmer, supra note 123.

128 Flatters, supra note 123.

129 Masson, supra note 5 at 45. 
broad and might be subject to abuse. ${ }^{130}$ Families thus may have greater security in terms of respect for their rights and privileges in conventional legal contexts. ${ }^{131}$

Our project thus does not seek to predict qualitative outcomes for children and families based on rates of court use in a given jurisdiction. Rather, we have committed ourselves to determining rates of court use - from data which is not easily discernable - and we have explored how these rates compare with our hypothesis regarding judiciarization based upon a legislative analysis. A more normative angle to this project might involve making recommendations about how to encourage or discourage the use of courts. Yet before this is possible, a rigorous evaluation of formal and informal dispute resolution mechanisms for addressing child protection issues is required. This analysis would benefit enormously from additional empirical work that considers the perspectives and experiences of families, young people, child welfare workers, as well as judges and mediators engaged in child welfare systems across Canada.

\section{CONCLUSION}

In weighing the implications of our findings it should be remembered that we tracked a very specific kind of court use, namely first-time visits. In reality children must often appear numerous times before courts to have their case or status reviewed. Looking at rates of status review could therefore arguably give a better sense of the everyday use of judicial resources for child protection cases. Yet our findings remain instructive given that they convey a sense of how often children affected by child welfare issues come into contact with the courts. Our study also provides an indication of the propensity of child welfare workers to choose judicial mechanisms over extra-judicial options.

The data uncovered through this project suggests that legislation does not, on its own, drive child-welfare workers' decisions about whether to refer a case to court. The fact that jurisdictions with legislative predictors indicating less reliance on judicial mechanisms nonetheless have a relatively large number of children being brought before the courts suggests that other factors are at play. Further research is therefore needed on the way child welfare workers perceive their decision-making process, as well as empirical research investigating how child protection workers understand child welfare legislation as influencing their day-to-day work.

Additional scholarship is also needed on the subject of whether the use of courts in child protection matters is beneficial or harmful to families and children. We refrained from making any normative statement on the issue in this article but it is a pressing question that needs to be addressed. Ideally, such research would have an empirical component to explore the experiences of each of the 'players' in the child welfare court system (children, families, judges, and mediators). Similarly, the characteristics of families and children who go to court need to be uncovered in order to determine whether the judicial system can manage their cases effectively.

130 Poirier, supra note 17.

131 Ibid.; Dumbrill, supra note 125. 